\title{
Demand Elasticities In Turkey
}

\author{
Huseyin Ozer \\ Ataturk University
}

\begin{abstract}
Demand elasticities are the best available indicators of how households may respond to policies which change relative prices and the level and distribution of income. In this study, income and price elasticities for eight commodity groups are estimated for Turkey based on the LES by using household level data compiled from the 1994 Household Income and Consumption Expenditures Survey conducted by the State Institute of Statistics. All estimates obtained as a result of the estimation procedure are consistent with a priori expectations and satisfy the underlying utility theory requirements.
\end{abstract}

- JEL Classifications: C31, D12

- Key words: Consumption expenditures, Demand elasticities, Linear expenditures system

\section{Introduction}

It is often crucial in the analysis of many economic issues to have a measure of the responsiveness or sensitivity in the quantity demanded of a particular commodity or commodity group to a change in its own price, in households' income, and in the price of other commodity groups. These define the price elasticity of demand, the income elasticity of demand, and the cross elasticity of demand, respectively.

The analysis of household expenditure behaviour has been attracting attention in the economic literature following the pathbreaking work of Engel in 1857. Price

\footnotetext{
*Corresponding address: Professor Huseyin Ozer Department of Economics, Faculty of Economics and Administrative Sciences, Ataturk University, 25240 Erzurum, Turkey Tel: +90 4422312105 E-mail

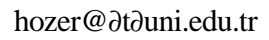
(C2003-Center for International Economics, Sejong Institution, All Rights Reserved.
} 
and income elasticities are vital parameters of household preferences and consumption behaviour. It is possible to obtain price elasticities indirectly by using the income elasticities (Kasnakoğlu, 1991: 111). It has been established in the literature that if preferences are characterized by a directly additive utility function, the price derivatives should be directly proportional to the income derivatives (see, Frisch (1959), Houthakker (1960) and Sato (1972)). Consequently, it must be assumed that household preferences are directly additive in order to drive price elasticities from income elasticities.

The main objective of this study is to develop a complete set of expenditure and price elasticities of household demand for Turkey through the Linear Expenditures System (LES) approach. The study will be based on the budget data compiled from the latest available household income and consumption expenditures survey (for the year 1994), conducted by the State Institute of Statistics (SIS) of Turkey.

The estimation of Engel curves has a long tradition in the empirical economics literature. Expenditure data for Turkey have been analyzed in this way, often as a basis for quantifying elasticities of demand for different types of commodities. In the course of these analyses a number of different functional forms for Engel curves have been postulated, estimated and compared ${ }^{1}$.

These studies, some of which are listed in Table 1, differ not only in their models, estimation methods, data sets, and the number of expenditure categories but also in their coverages. They have ranged from the fairly simple singleequation models, such as linear, double-logarithmic and semi-logarithmic, to complex, such as Working-Leser, Linear Expenditure System and the Almost Ideal Demand System.

The study of consumer responsiveness to changes in income and relative prices is carried out generally in a single-equation model. While the approach has the advantage of simplicity, its major shortcoming lies in the difficulty and often impossibility of deriving precise estimates of demand parameters since it omits the interrelationship among demand functions for different goods. This calls for a system approach which could allow one to model simultaneously the demand relations for an exhaustive list of the items in the consumer's budget, and also examine the estimated demand equations in the light of the properties of the established theory. Therefore, While Doğan (1995) has used a single-equation

\footnotetext{
${ }^{1}$ See, for example, Tansel (1986), Şenesen (1987), Kasnakoğlu (1991), Özmucur (1991), Selim (1993), Uygur (1993), Doğan (1995), Şenesen and Selim (1995), Nişanci (1998), and Özer (2001).
} 
Table 1. Survey of relevant literature on Turkey

\begin{tabular}{|c|c|c|c|c|c|c|c|}
\hline Study & Model & $\begin{array}{l}\text { Data } \\
\text { Year }\end{array}$ & Type & Coverage & Elasticity & $\begin{array}{c}\text { Estimation } \\
\text { Method }\end{array}$ & $\begin{array}{c}\text { Number of } \\
\text { Expenditure } \\
\text { Categories }\end{array}$ \\
\hline $\begin{array}{l}\text { Tansel } \\
(1986)\end{array}$ & $\begin{array}{l}9 \text { func- } \\
\text { tional } \\
\text { forms }\end{array}$ & $1978 / 79$ & Grouped & Urban & $\begin{array}{c}\text { Expenditure } \\
\text { Household } \\
\text { Size }\end{array}$ & GLS & 11 \\
\hline $\begin{array}{c}\text { Şenesen } \\
(1987)\end{array}$ & $\begin{array}{c}\text { Working- } \\
\text { Leser }\end{array}$ & $1978 / 79$ & Grouped & Urban & Expenditure & GLS & 11 \\
\hline $\begin{array}{l}\text { Kasna- } \\
\text { koğlu } \\
\text { (1991) }\end{array}$ & Double-log & 1987 & Grouped & $\begin{array}{l}\text { Overall } \\
\text { Regions }\end{array}$ & $\begin{array}{c}\text { Income } \\
\text { Household } \\
\text { Size }\end{array}$ & GLS & 11 \\
\hline $\begin{array}{c}\text { Özmucur } \\
(1991)\end{array}$ & $\begin{array}{l}9 \text { func- } \\
\text { tional } \\
\text { forms }\end{array}$ & 1987 & Grouped & Overall & Expenditure & OLS & 17 \\
\hline $\begin{array}{l}\text { Uygur } \\
\text { (1993) }\end{array}$ & Double-log & 1987 & Grouped & Overall & $\begin{array}{c}\text { Income } \\
\text { Expenditure } \\
\text { Household } \\
\text { Size }\end{array}$ & GLS & 11 \\
\hline $\begin{array}{c}\text { Doğan } \\
\text { (1995) }\end{array}$ & $\begin{array}{c}\text { Working- } \\
\text { leser } \\
\text { Double-log }\end{array}$ & 1987 & Grouped & $\begin{array}{l}\text { Overall } \\
\text { Rural/ } \\
\text { Urban } \\
\text { Regions }\end{array}$ & $\begin{array}{c}\text { Income } \\
\text { Expenditure } \\
\text { Household } \\
\text { Size }\end{array}$ & OLS & 11 \\
\hline $\begin{array}{l}\text { Selim } \\
(1993)\end{array}$ & $\begin{array}{l}9 \text { func- } \\
\text { tional } \\
\text { forms }\end{array}$ & 1987 & Grouped & $\begin{array}{l}\text { Overall } \\
\text { Rural/ } \\
\text { Urban }\end{array}$ & Expenditure & GLS & 10 \\
\hline $\begin{array}{l}\text { Senesen } \\
\& \text { Selim } \\
(1995)\end{array}$ & $\begin{array}{l}9 \text { func- } \\
\text { tional } \\
\text { forms }\end{array}$ & 1987 & Grouped & $\begin{array}{l}\text { Overall } \\
\text { Rural/ } \\
\text { Urban }\end{array}$ & Expenditure & GLS & 10 \\
\hline $\begin{array}{r}\text { Nişanci } \\
\text { (1998) }\end{array}$ & AIDS & 1994 & $\begin{array}{l}\text { House- } \\
\text { hold } \\
\text { Level }\end{array}$ & Urban & $\begin{array}{c}\text { Expenditure } \\
\text { Household } \\
\text { Size }\end{array}$ & SURE & 10 \\
\hline $\begin{array}{l}\text { Özer } \\
(2001)\end{array}$ & LES & $\begin{array}{l}1987 \\
1994\end{array}$ & $\begin{array}{l}\text { House- } \\
\text { hold } \\
\text { Level }\end{array}$ & $\begin{array}{c}\text { Overall } \\
\text { Rural/ } \\
\text { Urban } \\
\text { Regions }\end{array}$ & Expenditure & SURE & 8 \\
\hline This Study & LES & 1994 & $\begin{array}{l}\text { House- } \\
\text { hold } \\
\text { Level }\end{array}$ & Overall & Expenditure & SURE & 8 \\
\hline
\end{tabular}

Ordinary Least Squares (OLS) method and Nişanci (1998) and Özer (2001) have used Seemingly Unrelated Regression Estimation (SURE) method, the others have employed a single-equation Generalized Least Squares (GLS) method to estimate the models because the inclusion of same regressors in each equation of 
each functional form makes the system estimation equivalent to single-equation estimation (Bewley, 1982: 82-91).

Furthermore, all the studies are based on the household income and expenditure survey data. These surveys provide the single most important source of data on consumption pattern in Turkey. However, the analyses in the studies, with the exception of Özer (2001), are generally confined to single year only. The system approach, in general, makes it possible to carry out sophisticated research on consumer behavior even when available data on private consumption are inadequate. For Turkey, as for many developing countries, time series data on private consumption are not disaggregated over various commodity groups. As such one can only use cross section information for estimating demand parameters. In addition, the studies other than Nişanci (1998) and Özer (2001) have used grouped data and expenditure categories ranging from 8 to 17 .

The main objective of these studies has been to test the validity of the relationship between income and expenditure on different commodities, as summarized by the Engel's law. Some of them, e.g., Tansel (1986), Kasnakoğlu (1991), Uygur (1993), Doğan (1995), and Nişanci (1998) have also tested for the existence of economies of scale in consumption. The findings, in general, are in conformity with the Engel's law. The estimates also point to the existence of economies of scale in the consumption of certain commodities.

The remaining part of the paper is organized in the following way. The methodology of the study is introduced in the next section, presenting the model, the data used, and the estimation procedure of the model. Results are interpreted in the ensuing section and the conclusions of the study are stated in the final section.

\section{Methodology}

\section{A. The Model}

The choice of the appropriate functional form for Engel curves has received a great deal of attention recently. While earlier works were concerned with empirical determination of the best fitting functional form for expenditure groups separately, more recent studies consider alternative specifications derived explicitly from consumer theory satisfying its restrictions, and are concerned with the best fitting functional form for the complete system of Engel curves (Tansel, 
1986: 239).

A variety of complete systems of demand equations have been proposed for econometric use. Three broad categories of demand systems can be distinguished. The first category includes those systems that are derivable from maximization of a utility function subject to consumer's budget constraint and automatically satisfy the general restrictions of demand theory resulting in a corresponding reduction in the number of independent parameters that have to be estimated. However, the disadvantage of these systems is that they cannot be used to test whether the restrictions are satisfies by the data. The LES is a typical example of this approach that has $2 n-1$ independent parameters $\left(n \gamma_{i}^{\prime} \mathrm{s}\right.$ and $\left.n-1 \beta_{i}^{\prime} \mathrm{s}\right)$.

The LES automatically satisfies the theoretical restrictions, namely, adding-up, homogeneity of degree zero in prices and total expenditure, symmetry, and negative semidefiniteness of the Slutsky-Hicks substitution matrix. This is due to its functional form and the fact that it is derived from constrained maximization of a well-behaved utility function (the Samuelson-Geary utility function). Furthermore, the LES is the only theoretically plausible demand system, a demand system consistent with utility maximization, for which expenditure on each good is a linear function of all prices and total expenditure. A complete system of demand equations is said to be theoretically plausible if it is derivable from a well-behaved utility function, or, equivalently, if the demand equations are homogeneous of degree zero in prices and total expenditure, and the implied Slutsky matrix is symmetric and negative semidefinite (Pollak and Wales, 1978: 349).

The second category contains the empirical-based demand systems that do not satisfy all theoretical restrictions or satisfy them only approximately. Notable examples of this category are the double logarithmic system and the Rotterdam system. The disadvantages of this approach are, firstly, since it is begun the estimation procedure with no restrictions imposed it is faced with the problem of estimating a total of $n(n+1)$ price and total expenditure responses, where $n$ is the number of goods. Sample size limitations may then dictate a small $n$ in order to avoid the degrees of freedom problem. Secondly, while this approach may appear to circumvent the need to specify the precise form of the utility function, there is a risk of unintentionally imposing implausible restrictions on the underlying utility function by choosing a particular functional form for the demand equations.

The demand systems that satisfy the general restrictions without being derivable from maximization of a given direct utility function constitute the third category. 
The indirect translog demand system and the almost ideal demand system are the most prominent examples of this category. More flexible systems that admit nonlinear Engel curves, such as the AIDS or Indirect Translog System, involve a considerable number of parameters to be estimated even with a moderate number of commodity groups. Furthermore, the majority of these parameters are introduced to give a refined representation of the price response. If price variability is limited or absent, the attractiveness of such models' flexibility becomes a theoretical beauty. For example, the AIDS gives a rather rigid representation of the income response when all prices are constant; the budget share equations become merely linear functions of the logarithm of total expenditure (Gergis, 1995: 14-16).

At the present state of knowledge, there seems to be no consensus on the issue of the ideal functional form and the nature of the data usually prevents a clear-cut decision about the empirical superiority of any particular choice.

Its limitations notwithstanding, the LES is one of the most commonly estimated systems of demand equations in empirical demand analysis. Notable applications (only to mention a few) include Pollak and Wales $(1969,1978)$, Parks (1969), Yoshihara (1969), Goldberger and Gamaletsos (1970), Deaton (1975), Green et al (1987), Ahmad and Malik (1989), Buse (1992), Gergis (1995).

While the LES is linear in the variables, prices and total expenditure, it is nonlinear in the parameters, involving the product of $\beta_{i}$ and each $\gamma_{i}$ in a typical equation of the system. This is hardly a problem in today's nonlinear estimation techniques. A considerable amount of experience has been gained in estimating the LES with time series data and several methods of estimation have been developed (see, Howe, 1974: 109-115). However, cross-section application of the LES is much less common. The first application of the LES to cross-section data seems to be Belandria's (1971) analysis of household consumption in three Venezuelan cities (Gergis, 1995: 40).

In the cases of being limited or absent of price variation in the data, it must be assumed that household preferences are directly additive in order to derive price responses from income parameters. The best known utility function belonging to the directly additive class is the Samuelson-Geary utility function. The maximization of this utility function leads to the LES. According to Goldberger, the only linear expenditure system globally compatible with the maximization of a classical utility function is the LES. Furthermore, there is one and only one utility function whose maximization leads to the LES, namely, the Samuelson- 
Geary utility function which is directly additive (Goldberger, 1987: 43-64). Therefore, as a convenient analytical framework for the propose of this study, the LES is considered an appropriate choice to serve as the work horse for the study. In this study the LES introduced in the literature by Klein and Rubin (1947/48) in an attempt to construct a true cost-of-living index is considered. The LES derived from the maximization of the Samuelson-Geary utility function, which is also so-called as Klein-Rubin or Stone-Geary utility function although the form of the function was introduced by an assumption by Samuelson (1947/48) first and then proved by Geary (1949/50),

$$
\text { (1) } U=\sum_{i=1}^{n} \beta_{i} \log \left(q_{i}-\gamma_{i}\right)
$$

subject to the consumer's budget constraint

$$
\text { (2) } y=\sum_{i=1}^{n} p_{i} q_{i}
$$

can be written as

$$
\text { (3) } p_{i} q_{i}=p_{i} \gamma_{i}+\beta_{i}\left(y-\sum_{i=1}^{n} p_{i} \gamma_{i}\right)
$$$$
(\mathrm{i}=1, \ldots, \mathrm{n})
$$

where $p_{i}, q_{i}, \gamma_{i}$, and $\beta_{i}$ are respectively price, quantity consumed, committed or subsistence consumption quantity, and marginal budget share of commodity $i ; y$ is total expenditure (income); and $0<\beta_{i}<1, \sum_{i=1}^{n} \beta_{i}=1$, and for $\left(q_{i}-\gamma_{i}\right)>0$ all $i$.

The parameter $\gamma_{i}$ is sometimes called the subsistence parameter. This implies that the household first purchases $\gamma_{i}$ units of good $i$ at a cost of $p_{i} \gamma_{i}$, which is called committed or subsistence consumption. The total cost of subsistence is $\sum_{i=1}^{n} p_{i} \gamma_{i}$. This leaves $y-\sum_{i=1}^{n} p_{i} \gamma_{i}$ as supernumerary expenditure. Usually known as marginal expenditure shares, $\beta_{i}$ 's denote how a consumer allocates his supernumerary expenditure over different commodities.

The parameter $\gamma_{i}$ may be positive or negative. Positive $\gamma_{i}$ implies inelastic demand and negative $\gamma_{i}$ implies elastic demand. The LES does not allow price elasticities of demand to be larger than unity unless $\gamma_{i}$ is permitted to be negative. 
This can be seen from equation (5); given the requirement that $\left(q_{i}-\gamma_{i}\right)>0$, then $\gamma_{i} / q_{i}$ is less than one. It is also seen that $0<\beta_{i}<1$ for all $i$. Therefore, only if $\gamma_{i}$ is negative can the uncompensated own price elasticity exceeds one in absolute value.

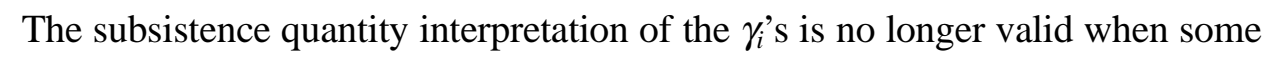
of them are negative, and hence it is not appropriate to regard the intercept terms as subsistence quantities unless they are assumed to be positive. If we restrict the $\gamma_{i}$ 's to being positive, then all commodities would be price inelastic, a condition that would not be a realistic assumption empirically. So we let the signs of the $\gamma_{i}$ 's be determined empirically.

The LES automatically satisfies the theoretical restrictions: Adding-up, homogeneity of degree zero in prices and total expenditure, symmetry, and negative semidefiniteness of the Slutsky-Hicks substitution matrix. This is due to its functional form and the fact that it is derived from constrained maximization of a well-behaved utility function (the Samuelson-Geary utility function). Furthermore, the LES is the only theoretically plausible demand system, a demand system consistent with utility maximization, for which expenditure on each good is a linear function of all prices and total expenditure.

Demand elasticities are the best available indicators of how households may respond to policies which change relative prices and the level and distribution of income. Based on the parameters estimated of the LES, it is possible to calculate all kinds of demand elasticities. Total expenditure (income) elasticities can be derived directly from the marginal and average budget shares $\left(\beta_{i}\right.$ and $w_{i=} p_{i}-q_{i / y}$, respectively). Moreover, as a result of the theoretical restrictions imposed on the LES (additivity of the Samuelson-Geary utility), price elasticities can be obtained from the parameter values of the LES.

The relevant demand elasticites can then be computed as follows:

(4) Total expenditure elasticity : $\eta_{i}=\beta_{i} / w_{i}$

(5) Uncompensated own price elasticity : $\varepsilon_{i i}=-1+\left(1-\beta_{i}\right) \gamma_{i} / q_{i}$

(6) Compensated own price elasticity: $\varepsilon_{i i}^{*}=\varepsilon_{i i}+\eta_{i} w_{i}$

(7) Uncompensated cross price elasticity: $\varepsilon_{i j}=-\beta_{i} p_{j} \gamma_{j} / p_{i} q_{i} \quad(\mathrm{i} \neq \mathrm{j})$

(8) Compensated cross price elasticity: $\varepsilon_{i j}^{*}=\varepsilon_{i j}+\eta_{i} w_{j}(\mathrm{i} \neq \mathrm{j})$.

Under the LES some theoretical expectations related to the elasticities can be expressed as follows. All expenditure elasticities are positive. Compensated own price elasticities are negative. Only if $\gamma_{i}$ is negative, can uncompensated own price elasticity exceeds one in absolute value. Further, all compensated cross price 
elasticities are positive although uncompensated cross price elasticities are negative unless $\gamma_{i}$ is negative.

\section{B. The Data}

One of the most important sources which gives information on socio-economic structures, living conditions and expenditure patterns of households in a given country is the household income and consumption expenditure survey.

This study is based on the monthly household level data of Household Income and Consumption Expenditure Survey for the year 1994, compiled by the SIS of Turkey. The survey was conducted from 01 January to 31 December 1994, at 236 settlements (62 urban and 174 rural) and to 26256 households ( 2188 households in each month rotely) selected by means of the stratified multi-stage systematic cluster sampling method to cover all households and settlements.

For purpose of estimation, the data were aggregated into eight expenditure categories on the basis of the homogeneous characteristics of commodities in the household's budget: namely food, clothing, furniture, health, housing, transportation and communication, culture, education and recreation, and miscellaneous.

Since the survey contains no data on prices, this information was collected from the 1995 Wholesale and Consumer Price Indexes Monthly Bulletin by SIS in terms of consumer price index for the commodity groups with 1987 as the base year.

\section{Estimation Method}

Substituting total expenditure for income, one of the most important factors affecting households' expenditures, in practice is not uncommon because, firstly income data generally suffer from measurement errors, and secondly, total expenditure better reflects the changes in permanent income (Siddiqui, 1982: 277). This study, following the mainstream, uses monthly expenditure as the explanatory variable rather than monthly disposable income.

Since the data is cross-sectional and may involve problem of heteroscedasticity because high-income households show a much greater variability in their consumption behavior than do low-income households, the Goldfeld-Quandt test was carried out, assuming that the heteroscedastic variance, $\sigma_{i}^{2}$, is proportional to the square of the total expenditure, $y$, that is,

(9) $\sigma_{i}^{2}=\sigma^{2} y^{2}$ 
where $\sigma^{2}$ is a constant. The test result has confirmed the validity of heteroscedasticity. To solve this problem the model (3) was transformed by dividing all the terms in the model by $y$

$$
\text { (10) } w_{i}=\frac{p_{i} q_{i}}{y}=\frac{p_{i} \gamma_{i}}{y}+\beta_{i}\left(1-\sum_{i=1}^{n} \frac{p_{i} \gamma_{i}}{y}\right) \text {. }
$$

Then, this model in share form was used for the purpose of estimation.

Since the expenditure shares of the eight different groups of commodities always add up to one, the sum of the disturbances across the eight equations is zero at each observation. This implies that the covariance matrix of the disturbance term will be singular. However, in order to ensure a nonsingular covariance matrix, the equation related to the commodity group of Miscellaneous was dropped from the system.

The demand system has a total of $2 n$ structural parameters, of which $2 n-1$ are independent parameters in view of the adding-up restriction. The independent parameters are $n-1 \beta$ 's and $n \gamma$ 's. Since these LES equations are highly interrelated, a system approach was used to estimate the parameters of the model.

\section{Results}

Parameter estimates and total expenditure elasticity measures are presented in Table 2, along with the values of the standard errors and R-squared coefficient.

The parameter estimates are consistent with a priori expectations. The estimates of the marginal budget shares $\left(\beta_{i}\right)$ are all positive as required by the underlying Samuelson-Geary utility function, valued between zero and one, and add-up to one (by restriction). All $\beta_{i}$ values are significantly different from zero at the 5 percent level.

As for the estimated values of the $\gamma_{i}$ parameters, not only are the $t$ values for all the $\gamma_{i}^{\prime} s$ statistically significant at $5 \%$ level, negative values were also encountered for all the commodity groups, except for food and housing, implying that the subsistence quantity interpretation of the $\gamma_{i}^{\prime} s$ is no longer valid and the commodities are price elastic.

The R-square values for the individual equations have been reported although they are not of particular significance because the estimation procedure involves a 
system of equation.

As is well known, expenditure elasticity of demand is used to classify goods as either normal or inferior. A commodity is normal if $\eta_{i}$ (expenditure elasticity) is positive and inferior if $\eta_{i}$ is negative. A normal good can be further classified as a necessity if $\eta_{i}$ is less than one and as a luxury if $\eta_{i}$ is greater than one.

As it is seen from Table 2, the expenditure elasticity for the food group is less than one, confirming the famous Engel's law which states that income elasticity of demand for food is always less than unity. Of the commodity groups, in addition to the food group, three are also classified as necessities; housing, furniture, and transportation and communication. Moreover, it is observed that only the health group has unitary elasticity while the others (namely clothing, culture, education and recreation, and miscellaneous) have elasticities above unity and are classified as luxuries.

The findings are found in quite conformity with previous studies in Turkey. In spite of differences in coverage, functional forms, and data set used, all studies in Turkey suggest very similar results in terms of total expenditure elasticities. While Doğan (1995) and \$̧enesen and Selim (1995) found only food to be a necessity, Tansel (1986), Şenesen (1987), Kasnakoğlu (1991), Özmucur (1991), Nişanci (1998), and Özer (2001) all found food and housing as necessity goods. In addition to these, clothing in Penesen and Kasnakoğlu's studies, furniture in Özer and Özmucur's studies, and transportation and communication in Şenesen and Özer's studies are also necessities. Health in \$̧enesen and Selim's study, along with furniture in Tansel's study and clothing, furniture, and housing in Doğan's study, was considered neither a luxury nor a necessity while it was classified as a necessity only in Özmucur's study.

Uncompensated price elasticities show the total effect of a price change and income compensated price elasticities measure the net substitution effect of that change. Price elasticities, both uncompensated and compensated, of demand for the commodity groups have been calculated on the basis of the LES parameter estimates in Table 2 and presented in Tables 3 and 4, respectively.

From Tables 3 and 4, it is seen that all estimates satisfy the underlying utility theory requirements (negative uncompensated and compensated own-price elasticities and positive compensated cross-price elasticities). Under the LES, the own-price elasticity exceeds one in absolute value whenever the corresponding $\gamma_{i}$ estimate is negative. This arises in all categories, except for food and housing. Uncompensated cross-price elasticities are positive in these instances. In the 
Table 2. Parameter estimates and expenditure elasticity measures

\begin{tabular}{lcccc}
\hline \multicolumn{1}{c}{ Commodity Groups } & $\gamma_{i}$ & $\beta_{i}$ & $R^{2}$ & $\eta_{\mathrm{i}}$ \\
\hline \multirow{2}{*}{ Food } & 110.608 & 0.333 & 0.45 & 0.935 \\
& $(7.502)$ & $(0.0033)$ & & \\
Clothing & -21.569 & 0.122 & 0.37 & 1.356 \\
Furniture & $(1.685)$ & $(0.0013)$ & & \\
& -44.548 & 0.088 & 0.18 & 0.978 \\
Health & $(2.893)$ & $(0.0018)$ & & \\
& -6.442 & 0.026 & 0.04 & 1.000 \\
Housing & $(0.770)$ & $(0.0007)$ & & \\
& 12.574 & 0.226 & 0.10 & 0.991 \\
Transportation and Communication & $(5.443)$ & $(0.0021)$ & & \\
& -29.434 & 0.070 & 0.14 & 0.795 \\
Culture, Education and Recreation & $(2.005)$ & $(0.0016)$ & & \\
& -20.672 & 0.038 & 0.14 & 1.027 \\
Miscellaneous & $(1.247)$ & $(0.0009)$ & 0.16 & \\
& -94.718 & 0.097 & & 1.141 \\
\hline
\end{tabular}

Note: The values in parentheses represent the standard errors of the estimates and the marginal budget share, $\beta$, related to the commodity group of miscellaneous was estimated as implied by the adding-up restriction.

Table 3. Uncompensated price elasticities of demand

\begin{tabular}{lccccccccc}
\hline \multicolumn{1}{c}{\begin{tabular}{c} 
Commodity \\
\multicolumn{1}{c}{ Groups }
\end{tabular}} & Food & \multicolumn{3}{c}{ Clothing Furniture } & Health & Housing & \multicolumn{3}{c}{ Trans. } \\
\& Com. & Cul.,Educ. & \& Recr. & Misc. \\
\hline Food & -0.884 & 0.012 & 0.019 & 0.004 & -0.005 & 0.015 & 0.009 & 0.031 \\
Clothing & -0.079 & -1.113 & 0.026 & 0.005 & -0.006 & 0.020 & 0.013 & 0.042 \\
Furniture & -0.061 & 0.012 & -1.211 & 0.004 & -0.005 & 0.016 & 0.010 & 0.033 \\
Health & -0.070 & 0.014 & 0.023 & -1.165 & -0.006 & 0.018 & 0.011 & 0.038 \\
Housing & -0.064 & 0.013 & 0.021 & 0.004 & -0.982 & 0.017 & 0.010 & 0.034 \\
Trans. \& Com. & -0.056 & 0.011 & 0.019 & 0.036 & -0.005 & -1.191 & 0.009 & 0.030 \\
Cul.,Educ.\&Recr. & -0.070 & 0.014 & 0.023 & 0.004 & -0.006 & 0.018 & -1.280 & 0.038 \\
Misc. & -0.075 & 0.015 & 0.025 & 0.005 & -0.006 & 0.019 & 0.012 & -1.373 \\
\hline
\end{tabular}

Note: The figures along the diagonal represent own-price elasticities and those off the diagonal are crossprice elasticities.

absence of negative $\gamma_{i}^{\prime}$ s, as is the case for food and housing, uncompensated crossprice elasticities are negative, indicating that income effects swamp substitution effects.

Income compensated own-price elasticities are lower in absolute value than those of the corresponding uncompensated elasticities. Since negative signs of cross-price elasticities denote complementarity between goods, food and housing 
Table 4. Compensated price elasticities of demand

\begin{tabular}{lccccccccc}
\hline \multicolumn{1}{c}{\begin{tabular}{c} 
Commodity \\
\multicolumn{1}{c}{ Groups }
\end{tabular}} & Food & \multicolumn{1}{c}{ Clothing } & Furniture & Health & Housing & \multicolumn{3}{c}{ Trans. } \\
\&Com. & Cul.,Educ. & \& Recr. & Misc. \\
\hline Food & -0.551 & 0.096 & 0.103 & 0.028 & 0.208 & 0.097 & 0.044 & 0.110 \\
Clothing & 0.404 & -0.991 & 0.148 & 0.040 & 0.303 & 0.139 & 0.063 & 0.146 \\
Furniture & 0.287 & 0.100 & -1.123 & 0.029 & 0.218 & 0.102 & 0.046 & 0.116 \\
Health & 0.286 & 0.104 & 0.113 & -1.139 & 0.222 & 0.106 & 0.048 & 0.123 \\
Housing & 0.289 & 0.102 & 0.110 & 0.030 & -0.756 & 0.104 & 0.047 & 0.118 \\
Trans. \& Com. & 0.227 & 0.083 & 0.091 & 0.057 & 0.176 & -1.121 & 0.038 & 0.098 \\
Cul.,Educ.\&Recr. & 0.296 & 0.106 & 0.115 & 0.031 & 0.228 & 0.108 & -1.242 & 0.125 \\
Misc. & 0.331 & 0.118 & 0.128 & 0.035 & 0.254 & 0.119 & 0.054 & -1.276 \\
\hline
\end{tabular}

Note: The figures along the diagonal represent own-price elasticities and those off the diagonal are crossprice elasticities.

are gross complements as indicated by the negative signs of uncompensated crossprice elasticities. Positive signs of the compensated cross-price elasticities indicate that all commodities are net substitutes as they should be in the LES.

\section{Conclusion}

This study attempts to carry out a quantitative assessment of consumer responsiveness to changes in income and commodity prices. The methodology adopted was based on a system approach known as the LES and the data used were household level data derived from the most recent household income and consumption expenditures survey, namely that for 1994, conducted by the SIS of Turkey.

All estimates obtained as a result of the estimation procedure are consistent with a priori expectations and satisfy the underlying utility theory requirements. The commodity groups for which expenditure elasticity of demand comes out to be less than one (i.e. the items which can be classified as necessities) include food, housing, furniture, and transportation and communication. On the other hand, clothing, culture, education and recreation, and miscellaneous have expenditure elasticities above unity and are classified as luxuries while only health has unitary elasticity. Furthermore, the estimated values of the price elasticities have shown that all commodities are net substitutes while only food and housing are gross complements.

Finally, keeping in mind the difficulties in comparing elasticities based on different data sets collected by different procedures and estimated by different 
methods, the estimates of total expenditure elasticities in this study appear to be consistent with expectations and with those in previous studies in Turkey.

\section{Acknowledgement}

The author would like to express his gratitude to anonymous referees of this journal for their helpful comments for improving this paper. He is also grateful to Professor Muammer Yaylal $_{i}$ for his valuable suggestions and constant encouragement. The author alone, however, is responsible for any remaining errors.

Received 18 January 2002, Accepeted 30 April 2002

\section{References}

Ahmad, E., Malik, N. (1989), Rural-Urban and Provincial Differences in Household Expenditure Pattern in Pakistan, Pakistan Journal of Economics, 8(2): 117-34.

Belandria, F. (1971), An Empirical Study of Consumer Expenditure Patterns in Venezuelan Cities, Northwestern Univ., (Unpublished Ph.D. Dissertation)

Bewley, R.A. (1982), On the Functional Form of Engel Curves: The Australian Household Expenditure Survey 1975-76, Economic Record, 58: 82-91.

Buse, A. (1992), Aggregation, Distribution and Dynamics in the Linear and Quadratic Expenditure Systems, Review of Economics and Statistics, 74(1): 45-53.

Deaton, A. (1975), Models and Projections of Demand in Post-War Britain, London: Chapman and Hall.

Doğan, H.C. (1995), An Estimation of Engel Curves by Regions and Income Groups in Turkey: 1987, Ankara: Graduate School of Social Sciences of Middle East Technical University, (Unpublished Master Thesis).

Engel, E. (1857), Die Productions-und Consumtionsverhaltnisse des Könichreichs Sachsen, in Zeitscrift des Statistischen Büreaus des Königlich Sächsischen Ministeriums des Innern, 8-9: 1-54, (reprinted in the Bulletin de I'Institut International de Statistique, 9: 1895).

Frisch, R. (1959), A Complete Scheme for Computing All Direct and Cross Price Elasticities in a Model with Many Sectors, Econometrica, 27: 177-96

Geary, R.C. (1949/50), A Note on 'A Constant-Utility Index of the Cost of Living', Review of Economic Studies, 18: 65-66.

Gergis, A.T. (1995), Household Consumption Analysis: Patterns of Behavior and Distribution in Egypt, Boston: Boston Univ. Graduate School, (Unpublished Ph.D. Dissertation)

Goldberger, A.S. (1987), Functional Form and Utility: A Review of Demand Theory, 
Westview Press, Inc.: 43-64)

Goldberger, A.S., Gamaletsos, T. (1970), A Cross-Country Comparison of Consumer Expenditure Patterns, European Economic Review, 1: 357-400.

Green, R.D., Hassan, Z.A., Johnson, S.R. (1987), Persistence in Consumption Patterns: Alternative Approaches and An Application of the Linear Expenditure System, in Food Demand Analysis: Problems, Issues, and Empirical Evidence, (ed.) by R. Raunikar and C.L. Huang, Ames: Iowa State Univ. Press, 114-27.

Houthakker, H.S. (1960), Additive Preferences, Econometrica, 28(2): 244-57.

Howe, H.J. (1974), Estimation of the Linear and Quadratic Expenditure Systems: A Cross-Section Case for Colombia, Univ. of Pennsylvania, (Unpublished Ph.D. Dissertation)

Kasnakoğlu, Z. (1991), Regional Consumption Patterns and Income Elasticities in Turkey:1987, Journal of Economic Cooperation Among Islamic Countries, 12:111116.

Klein, L.R., Rubin, H. (1947/48), A Constant-Utility Index of the Cost of Living, Review of Economic Studies, 15 (38): 84-87.

Ni şanci, M. (1998), Türkiye'de Tüketici Harcamalarinin Analizi: Ídeale Yakin Talep Sistemi Uygulamasi, Erzurum: Atatürk Üniversitesi Sosyal Bilimler Enstitüsü, (Unpublished Master Thesis).

Özer, H. (2001), Türkiye'de Hanehalki Tüketim Harcamalarinin Doğrusal Harcama Sistemi Yakla şimiyla Analizi, Ankara: Devlet İstatistik Enstitüsü Matbaasi, Yayin No: 2463.

Özmucur, S. (1991), Tüketim Kaliplari; 1987, İstanbul: Boğaziçi Üniversitesi Sosyal Bilimler Enstitüsü, ISS/EC 91-07, (Working Paper).

Parks, R.W. (1969), Systems of Demand Equations: An Empirical Comparison of Alternative Functional Forms, Econometrica, 37(4): 629-50.

Pollak, R.A., Wales, T.J. (1969), Estimation of the Linear Expenditure System, Econometrica, 37(4): 611-28.

Pollak, R.A., Wales, T.J. (1978), Estimation of Complete Demand Systems from Household Budget Data: The Linear and Quadratik Expenditure Systems, American Economic Review, 68 (3): 348-59.

Samuelson, P. A. (1947/48), Some Implications of 'Linearity', Review of Economic Studies, 15: 88-90.

Sato, K. (1972), Additive Utility Functions and Double-Log Consumer Demand Functions, Journal of Political Economy, 80: 102-24.

Selim, R. (1993), Türkiye Tüketim Harcamalari Davraniş Denklemleri (1987), Istanbul : Istanbul Teknik Üniv. Fen Bil. Ens., (Unpublished Master Thesis)

Şenesen, G.G. (1987), İstanbul'da Yaşayanlarin Harcama Kaliplarina İlişkin Bir Deneme, XI. Ulusal Yöneylem Araştirmasi Kongresi Bildiriler Kitabi, VI:18- VI:31.

Şenesen, Ü., Selim, R. (1995), Consumption Patterns of Turkish Urban and Rural Households in 1987, Middle East Technical University Studies in Development, 22 (2): 207-20. 
Siddiqui, R. (1982), An Analysis of Consumption Pattern in Pakistan, The Pakistan Development Review, 21 (4): 275-296.

SIS (1995), Wholesale and Consumer Price Indexes Monthly Bulletin; January-1995, Ankara: State Institute of Statistics, Printing Division.

SIS (1997), Household Income and Consumption Expenditure Survey: 1994, Ankara: State Institute of Statistics, Printing Division.

Tansel, A. (1986), An Engel Curve Analysis of Household Expenditure in Turkey 197879, Middle East Technical University Studies in Development, 13 (3-4): 239-57.

Uygur, S. (1993), Gelir ve Harcama Esneklikleri, Ankara: Devlet İstatistik Enstitüsü

Yoshihara, K. (1969), Demand Functions: An Application to the Japanese Expenditure Pattern, Econometrica, 37(2): 257-74. 